\title{
Special issue: Ethical finance and governance. Introduction
}

\author{
Jean-Michel Sahut • Lorne N. Switzer
}

Published online: 11 May 2013

(C) Springer Science+Business Media New York 2013

The articles for this issue of the Journal of Management and Governance were selected from papers delivered at a conference on Ethical Finance \& Governance held at IPAG in Paris, France, in December 2011. The conference focused on governance mechanisms that can enhance performance and ethical behavior of firms and managers outside of the US context. The regions that are represented in these articles include both the European Union and Latin America, where the legal and institutional frameworks have been deemed by many observers to be less accommodative to shareholder rights and corporate social responsibility initiatives.

Bahram Soltani's article, "Importance of core values of ethics, integrity, and accountability in the European corporate governance codes" argues that revisions in the governance codes of five major European countries after 2002 and 2007 do take into account shareholder rights and board responsibility. However, the author suggests that further revisions are necessary to better incorporate ethical values, management integrity, and accountability.

In the article "Hit and Run and Revolving Doors: Evidence from the Italian Stock Market,"Pierpaolo Pattitoni Barbara Petracci, and Massimo Spisni show that minority shareholders in Italy are vulnerable to expropriation by managers who go private with their firms a few years after the IPO. They suggest that such behavior violates the principle of market egalitarianism (equal treatment of all investors).

J.-M. Sahut $(\bowtie)$

Geneva School of Business Administration, University of Applied Sciences, Geneva, Switzerland e-mail: jmsahut@gmail.com

J.-M. Sahut

CEREGE EA 1722, University of Poitiers, Poitiers, France

L. N. Switzer

John Molson School of Business, Concordia University, 1455 de Maisonneuve Blvd. W., Montreal, QC H3G 1M8, Canada

e-mail: switz@jmsb.concordia.ca 
They propose that legislators and regulators devise policies to better protect minority shareholders against such strategies.

In "On the Drivers of Corporate Social Responsibility in Banks: Evidence from an Ethical Rating Model," Giuliana Birindelli, Paola Ferretti, Mariantonietta Intonti, and Antonella Iannuzzi assess ethical performance using CSR principles. They show that while large European banks are sensitive to social and environmental variables in their ratings system, they could improve their performance by reinforcing CSR disclosure and by better adhering to international CSR norms.

In "Does the board of directors affect cash holdings? A study of French listed firms," Sabri Boubaker, Imen Derouiche, and Duc Khuong Nguyen show that certain elements of board structure can be used to reduce agency costs that adversely affect shareholders in French firms. In particular, they show that board independence and CEO/Board Chair separation are associated with less cash hoarding by firms.

In "Ethical Finance as a Response to the Financial Crisis: An Empirical Survey of European SRF Performance," Francesco Gangi and Carmen Trotta examine the benefits to "Ethical Investing" during periods of financial distress. The authors compare the performance of a sample of socially responsible funds (SRFs) versus conventional funds, focusing on the behavior of their returns over crisis periods. The authors show that while the relative performance of SRFs is variable across time, they provide greater stability during bear phases of the market.

In "Intraday Market Liquidity, Corporate Governance, and Ownership Structure in Markets with Weak Shareholder Protection: Evidence from Brazil and Chile," Diego Cueto and Lorne Switzer examine the effects of very highly concentrated ownership structures on the liquidity of stock markets in firms in Brazil and Chile, countries with relatively weak legal protection of minority shareholders. They show that dominant shareholders are not detrimental to market liquidity, since they have incentives to reduce their costs of exit and/or to improve the information transfer of their value enhancing activities to markets. Cross-listing in the US market and the threat of outside takeovers also serve as monitoring devices to reduce the adverse ethical effects associated with informational asymmetry.

\section{Author Biographies}

Jean-Michel Sahut is Professor at Geneva School of Business Administration, University of Applied Sciences (Ch). He teaches Corporate Finance, Financial Accounting and Management for engineering and management students. Previously, he was Associate Dean for Research at Amiens School of Management (Fr), Professor of Finance at Telecom \& Management Paris Sud (Fr) and director of the RESFIN Laboratory. He has published more than sixty articles about finance, governance, financial accounting and services in international peer review journals and five books.

Lorne N. Switzer is Professor of Finance and the Van Berkom Endowed Chair in Small Cap Equities at the John Molson School of Business of Concordia University. He has published several academic articles and books and serves on the Editorial Boards of European Financial Management, La Review Financier, and the International Journal of Business. He has done consulting work for many business firms and government organizations including the Bourse de Montréal, Caisse de Dépot et Placement du Québec, 
AMI Partners, Inc., Bank Credit Analysts Research Group, the Government of Canada, and the Gouvernement du Québec. He is a graduate of the Wharton School of the University of Pennsylvania, and obtained his Ph.D. from the University of Pennsylvania in 1982. 